\title{
Article
}

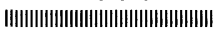

\section{Selective Detection Using Pulse Time Interval Analysis for Correlated Events in Rn-progeny with a Microsecond Lifetime}

\author{
Yukihisa Sanada, Hirohide Kobayashi, Sadaaki Furuta, \\ Kazuhiko Nemoto * , Keiichi $\mathrm{K}_{\mathrm{AwaI}}{ }^{*}$ and Tetsuo Hashimoto ** \\ Radiation Protection Department, Nuclear Fuel Cycle Engineering Research Laboratories, \\ Japan Atomic Energy Agency \\ 4-33 Muramatsu Tokai-mura, Naka-gun, Ibaraki Pref. 319-1194, Japan \\ * Japan Radiation Engineering Company Ltd. \\ 1-5-2 Sakuragawa-cho, Hitachi-shi, Ibaraki Pref. 316-0002, Japan \\ ** Faculty of Science, Niigata University \\ 2-8050 Igarashi, Niigata-shi, Niigata Pref. 950-2181, Japan
}

Received May 12, 2006

\begin{abstract}
Time interval analysis (TIA), which is one type of delayed coincidence method, was applied to ${ }^{214} \mathrm{Bi}-{ }^{214} \mathrm{Po}$ correlated events with a microsecond scale $\left({ }^{214} \mathrm{Po}\right.$ half-life : $\left.164 \mu \mathrm{s}\right)$. A measurement system with a silicon semiconductor detector was constructed in combination with a special time recording device and a personal computer. This system was designed to shorten dead time. The basic performance of this system was examined using an electrodeposited ${ }^{230} \mathrm{Th}$ source and actual dust samples. The measurement data for the time intervals of neighboring pulses were analyzed by a single time interval analysis (STA).

The following results were obtained.

(1) The ${ }^{214} \mathrm{Bi}-{ }^{214} \mathrm{Po}$ correlated events, which are included in $\mathrm{Rn}$-progeny, were used for sensitive measurement by the TIA method. (2) Theories for ${ }^{214} \mathrm{Po}$ measurement using the TIA method were established. (3) The measurement system for ${ }^{214} \mathrm{Po}$ was developed. (4) Efficiency and detection limit of measurement system were discussed through the experiment with an electrodeposited ${ }^{230} \mathrm{Th}$ source and dust samples.

The present method is applicable to on-line monitoring of $\alpha$-ray measurements, because the TIA method is able to detect any artificial $\alpha$-decay radionuclides by compensating for disturbance due to Rn-progenies.
\end{abstract}

Key Words : time interval analysis, radon progeny, thorium-230, bismuth-214 polonium-214 correlated event, air dust, $\alpha$-ray spectrum

\section{Introduction}

From the viewpoint of radiation protection, rapid and accurate detection of radioactivity due to nuclear materials in workplaces of nuclear facility is important to reduce internal radiation exposure of workers. The sensitive detection of the contamination of artificial radionuclides is usually disturbed by ${ }^{214} \mathrm{Po}$, progeny of ${ }^{222} \mathrm{Rn}$, which emits high energy $\alpha$-rays (7.69 $\mathrm{MeV})$. Radioactivities of artificial radionuclides will be determined more rapidly and accurately by compensating for disturbance of ${ }^{214} \mathrm{Po}$ radioactivity.

Several methods have been reported for measurement by compensating for disturbance of ${ }^{214} \mathrm{Po}$ radioactivity. Those methods can be classified into the two types, depending on the use of pulse time intervals ${ }^{1 / 3)}$ and/or the use of $\alpha$-ray energy spectrum ${ }^{4,5)}$. The method of the $\alpha$-ray energy spectrum can not be clearly resolved due to its self-absorption. In addition, a 
radiochemical pretreatment to reduce $\alpha$-ray self-absorption takes a long time.

On the other hand, a time interval analysis (TIA) has been developed for the measurement of short-lived nuclides of millisecond scale such as ${ }^{220} \mathrm{Rn}-{ }^{216} \mathrm{Po} \quad\left(\mathrm{T}_{12}=145 \mathrm{~ms}\right.$, Th-series $)$ and ${ }^{219} \mathrm{Rn}-{ }^{215} \mathrm{Po}\left(\mathrm{T}_{12}=1.78 \mathrm{~ms}\right.$, Ac-series $)$ using a liquid scintillation detector ${ }^{6), 7}$. However, the detection of ${ }^{214} \mathrm{Bi}-{ }^{214} \mathrm{Po} \quad\left(\mathrm{T}_{12}=164 \mu \mathrm{s}\right.$, U-series $)$ in a dust sample has been very difficult because the measurement system has too long dead time (order of several milliseconds) owing to slow data processing speed of CPU. Recently, the electronic technology, which is necessary for data acquisition processing, has been significantly advanced and a measurement system for ${ }^{214} \mathrm{Po}$ radioactivity with high speed processing has been realized by adopting up-to-date electronic technology.

The aim of this work is to measure the ${ }^{214} \mathrm{Bi}-$ ${ }^{214} \mathrm{Po}$ correlated events in actual dust samples using a newly developed device with a TIA method. The new measurement system could shorten dead time of both hardware and software. Effectiveness of the TIA method was proved from experimental results using the electrodeposited ${ }^{230} \mathrm{Th}$ source and the actual dust samples from a nuclear facility.

\section{Materials and Methods}

\section{$2 \cdot 1$ Measurement system}

A block diagram of the measurement system with the TIA method is shown in Fig. $1 . \alpha$ and $\beta$-rays were detected directly with the Si semiconductor detector (Canberra; PIPS detector with $450 \mathrm{~mm}^{2}$ active area). Pulses generated from radiation events were amplified and converted to digital signals from analogue signals by an analogue-to-digital converter (ADC) with

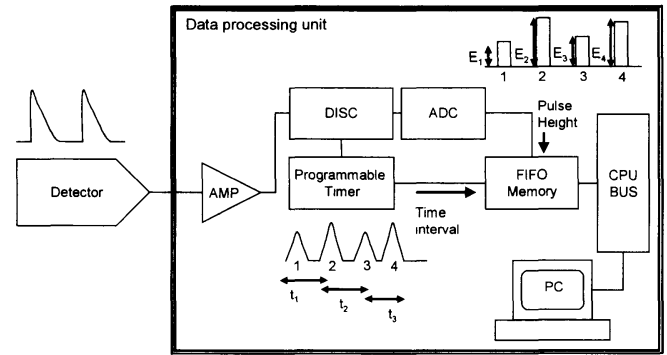

Fig. 1 Block diagram of measurement system using the TIA method. System dead time was $19 \mu \mathrm{s}$.

fixed dead time. The pulse generating time and pulse height was listed sequentially (List mode data acquisition) in the FIFO memory (Fast-in Fast-out). The measurement data was transferred into the personal computer (PC) memory. This data was subjected to the time interval analysis. This analyzed data could be read as Microsoft Excel file. Dead time of this system was determined as $19 \mu$ s by providing standard pulses from a pulse generator. This system was expected to measure the pulse time intervals with higher time resolution than a conventional $\alpha$-ray spectrometry system with dead time of $50-100 \mu$ s.

Time interval distribution between one event and subsequent events within a certain time period were determined from the measurement data of the pulse generating time ${ }^{6,7)}$. Detection theories based on ${ }^{214} \mathrm{Bi}-{ }^{214} \mathrm{Po}$ correlated events is described as follows. A single time interval analysis (STA), using neighboring pulses, was adopted ${ }^{6,7)}$. The counting rate of ${ }^{214} \mathrm{Bi}-{ }^{214} \mathrm{Po}$ correlated events, $\mathrm{N}_{\mathrm{C}}(\mathrm{T})$, can be given with the following equation :

$$
\mathrm{N}_{\mathrm{C}}(\mathrm{T})=\mathrm{M}_{\mathrm{C}} \cdot \exp (-\lambda \cdot \mathrm{T})
$$

where

$\mathrm{M}_{\mathrm{c}}$ : total counting rate of ${ }^{214} \mathrm{Bi}-{ }^{214} \mathrm{Po}$ correlated events [cps];

$\lambda$ : decay constant of ${ }^{214} \mathrm{Po}\left[\mathrm{s}^{-1}\right]$; 


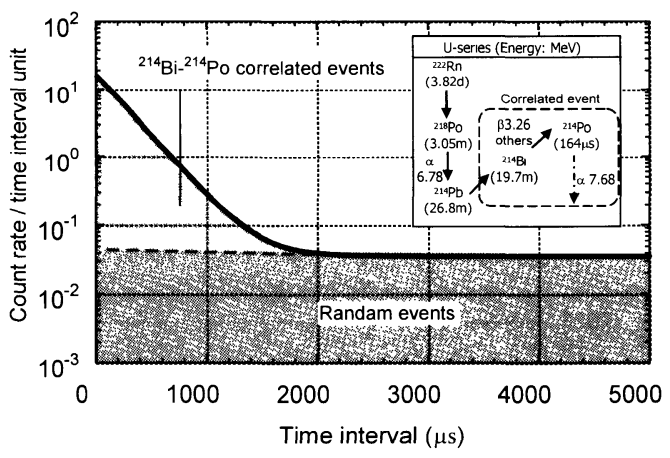

Fig. 2 Theoretical time spectrum of U-series by the TIA method.

\section{$\mathrm{T}$ : time interval [s].}

Radionuclide decay events with long half-life were expressed as "random events" against ${ }^{214} \mathrm{Bi}-{ }^{214} \mathrm{Po}$ correlated events. Neighboring pulses of random events depended on the total counting rate because these pulses were uncorrelated to each other. Counting rate of random events, $N_{R}(T)$, can be given with the following equation :

$$
\mathrm{N}_{\mathrm{R}}(\mathrm{T})=\mathrm{C} \cdot \exp (-\mathrm{C} \cdot \mathrm{T})
$$

where

\section{$\mathrm{C}$ : total counting rate of random events [cps].}

The time interval spectrum was plotted as a function of the time interval (unit : $10 \mu \mathrm{s}$ ). The time interval spectrum including the ${ }^{214} \mathrm{Bi}-{ }^{214} \mathrm{Po}$ correlated events and the random events are plotted using the theoretical equations (1) and (2) as seen in Fig. 2, where the decay constant of ${ }^{214} \mathrm{Po}(\lambda)$ is much larger than total counting rate of random events $(C)$. In this figure, the ${ }^{214} \mathrm{Bi}-{ }^{214} \mathrm{Po}$ correlated events are clearly distinguishable from the random events by selecting the ${ }^{214} \mathrm{Bi}-{ }^{214} \mathrm{Po}$ correlated events which appear from 0 to $1 \mathrm{~ms}$.

\section{$2 \cdot 2 \quad$ Data analysis}

${ }^{214} \mathrm{Po}$ radioactivities were determined by following procedures for Microsoft Excel in which the measurement data were recorded. The counting rate of $\alpha$-ray in a $0-1$ ms time interval $\left[\mathrm{N}_{0-1 \mathrm{~ms}}\right]$ is determined by a time interval spectrum shown as Fig. 2. The ratio of the counting rate of $\alpha$-ray in a $0-1 \mathrm{~ms}$ time interval [ $\left.\mathrm{N}_{0-1 \mathrm{~ms}}\right]$ to the total $\alpha$-ray counting rate of the all time intervals was expressed as efficiency for ${ }^{214} \mathrm{Bi}-{ }^{214} \mathrm{Po}$ correlated events $\left[\varepsilon_{\text {corr }}\right.$. ${ }^{214} \mathrm{Po}$ radioactivities [A $\left.\mathrm{AP}-214\right]$ were determined from the counting rate of $\alpha$-ray in a $0-1 \mathrm{~ms}$ time interval [ $\mathrm{N}_{0-1 \mathrm{~ms}}$ ] using the efficiency for ${ }^{214} \mathrm{Bi}-$ ${ }^{214} \mathrm{Po}$ correlated events and the counting efficiency [ $\varepsilon_{\mathrm{det}}$ ] for $\alpha$-ray of ${ }^{214} \mathrm{Po}$ for the $\alpha$-ray measurement geometry. ${ }^{214} \mathrm{Po}$ radioactivities can be given with equation (3).

$$
\mathrm{APo}-214=\frac{\mathrm{N}_{0-1 \mathrm{~ms}}}{\varepsilon_{\mathrm{det}} \cdot \varepsilon_{\mathrm{corr}}}
$$

\section{$2 \cdot 3 \quad$ Sample preparation}

The performance of the system for measurement the ${ }^{214} \mathrm{Bi}-{ }^{214} \mathrm{Po}$ correlated events was examined using the electrodeposited ${ }^{230} \mathrm{Th}$ source (10 $\mathrm{mm} \phi$ ) because ${ }^{222} \mathrm{Rn}$-progeny are produced in the electrodeposited ${ }^{230} \mathrm{Th}$ source $\mathrm{e}^{8}$. A spectrum of the electrodeposited ${ }^{230} \mathrm{Th}$ source obtained with the $\mathrm{Si}$ semiconductor detector is shown in Fig. 3 (a). In this figure, the energy resolution is poor due to $\alpha$-ray self-absorption in the electrodeposited ${ }^{230} \mathrm{Th}$ source. The ROIs (Regions of interest) for $\beta$-rays $(1-2 \mathrm{MeV}$ ) from ${ }^{214} \mathrm{Bi}$ and $\alpha$-rays $(7-8 \mathrm{MeV})$ from ${ }^{214} \mathrm{Po}$ were used for selection of the ${ }^{214} \mathrm{Bi}-{ }^{214} \mathrm{Po}$ correlated events using pulse height data. The ${ }^{211} \mathrm{Bi}$ $\left.{ }^{214} \mathrm{Po}\right)$ radioactivity in the electrodeposited ${ }^{230} \mathrm{Th}$ source was determined as $6.2 \mathrm{~Bq}$ from $\gamma$-ray spectrometry on the assumption that ${ }^{214} \mathrm{Bi}$ and ${ }^{214} \mathrm{Po}$ are in radioactive equilibrium.

In practical experiments, the dust samples were collected in the workplaces at the nuclear fuel reprocessing facility to determine the ${ }^{214} \mathrm{Bi}-$ 

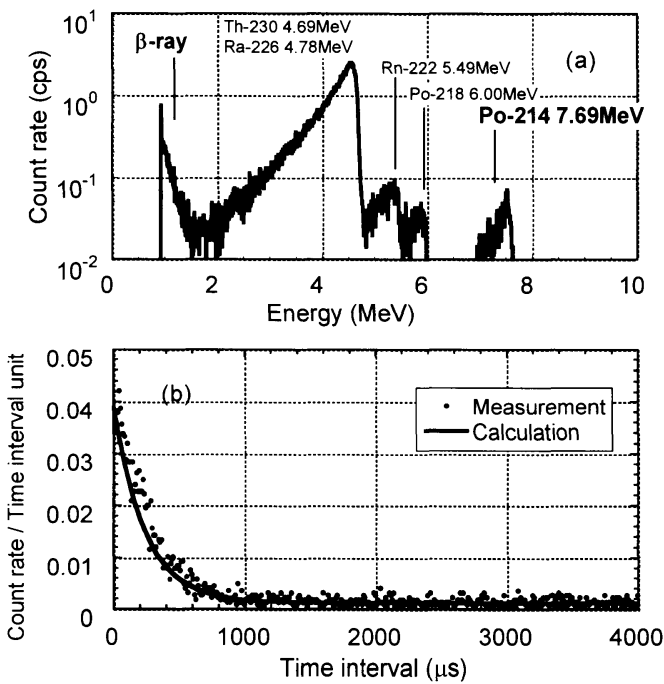

Fig. 3 (a) $\alpha$-ray energy spectrum of the electrodeposited ${ }^{230} \mathrm{Th}$ source measured with $\mathrm{Si}$ semiconductor detector. (b) Time interval spectra of the electrodeposited ${ }^{230} \mathrm{Th}$ source $\left({ }^{214} \mathrm{Po}: 6.2 \mathrm{~Bq}\right)$. The solid line represents the theoretical time interval spectrum calculated with equations (1) and (2) (time interval unit: $10 \mu \mathrm{s})$.

${ }^{214}$ Po correlated events. Dust was collected for 1 hour on a filter paper (HE-40T type $45 \mathrm{~mm} \phi$; pore size $8 \mu \mathrm{m}$ ) at sampling rate of $50 \mathrm{~L} / \mathrm{min}$. Measurements were done as soon as possible after collection.

\section{Results and Discussion}

\section{$3 \cdot 1$ Time interval spectrum}

A time interval spectrum was obtained from plotting data of the electrodeposited ${ }^{230} \mathrm{Th}$ source (Fig. 3(b)), and it was compared with the theoretical spectrum curve by equation(1) (solid line in the Fig. 3(b)). The counts number derived of the ${ }^{214} \mathrm{Bi}-{ }^{214} \mathrm{Po}$ correlated events are clearly observed for the $0-1 \mathrm{~ms}$ time interval region. The experimentally measured time interval spectrum of the electrodeposited ${ }^{230} \mathrm{Th}$ source is in good agreement with the theoretical one. In addition, the half-life of $170 \pm 12 \mu \mathrm{s}$,

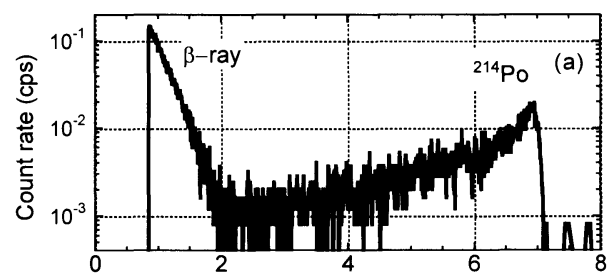

Energy (MeV)

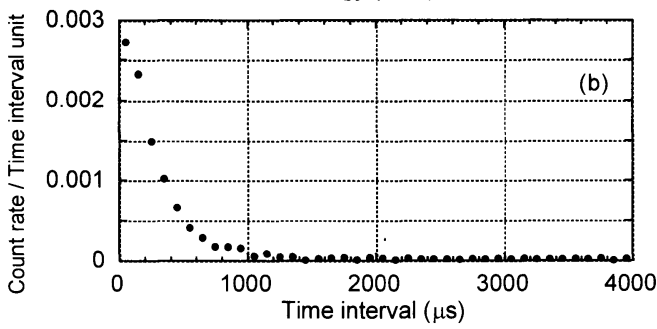

Fig. 4 (a) $\alpha$-ray energy spectrum of the dust sample collected on a filter paper (HE-40T type) measured with $\mathrm{Si}$ semiconductor detector. (b) Time interval spectrum of the dust sample (time interval unit: $100 \mu \mathrm{s}$ ).

which is determined from slope of the fitting curve at region of $0-1 \mathrm{~ms}$, agrees well with the reported half-life $164 \mu$ s of ${ }^{214} \mathrm{Po}$.

A pulse height spectrum of the dust sample measured with the Si semiconductor detector is shown in Fig. 4 (a). The energy regions of $\beta$ rays emitted from ${ }^{214} \mathrm{Bi}$ and $\alpha$-rays emitted from ${ }^{214} \mathrm{Po}$ are broader than the two energy spectrum of the electrodeposited ${ }^{230} \mathrm{Th}$ source by $\alpha$-ray self-absorption. The time interval spectrum measured for the dust sample is shown in Fig. 4(b). The counts number of the ${ }^{214} \mathrm{Bi}-{ }^{214} \mathrm{Po}$ correlated events is clearly observed for the $0-1 \mathrm{~ms}$ time interval. Furthermore, the half-life of $175 \pm 13 \mu$ s is determined from the slope of the fitting curve at region of $0-1$ ms.

These experimental results clearly support that ${ }^{214} \mathrm{Po}$ can be selectively measured by the TIA method. 

correlated events in Rn-progeny with a microsecond lifetime

$3 \cdot 2$ Detection efficiency for correlated events

The counting efficiency for $\alpha$-rays of ${ }^{214} \mathrm{Po}$ $\left[\varepsilon_{\text {det }}\right]$ and the efficiency for ${ }^{214} \mathrm{Bi}-{ }^{214} \mathrm{Po}$ correlated events $\left[\boldsymbol{\varepsilon}_{\text {corr }}\right]$ were determined by measuring the electrodeposited ${ }^{230} \mathrm{Th}$ source for $500 \mathrm{~s}$. In order to calculate the counting efficiency for $\alpha$-ray of ${ }^{214} \mathrm{Po}\left[\varepsilon_{\text {det }}\right]$ and the efficiency for ${ }^{214} \mathrm{Bi}-$ ${ }^{214} \mathrm{Po}$ correlated events $\left[\varepsilon_{\text {corr }}\right], 30$ measurements of the electrodeposited ${ }^{230} \mathrm{Th}$ source for 100 s were done. The counting efficiency for $\alpha$ ray of ${ }^{214} \mathrm{Po}\left[\varepsilon_{\text {det }}\right]$ and efficiency for ${ }^{214} \mathrm{Bi}-{ }^{214} \mathrm{Po}$ correlated events $\left[\varepsilon_{\text {corr }}\right]$ are $32.0 \pm 3.1 \%$ and $43.4 \pm 4.1 \%$, respectively. Namely, the ratio of detected ${ }^{214} \mathrm{Po}$ in the electrodeposited ${ }^{230} \mathrm{Th}$ source is determined to be approximately $12 \%$ $(=0.32 \times 0.43)$ in this system.

The efficiency for the dust on the filter paper (HE-40T type) is predicted to be lower than the efficiency for the electrodeposited ${ }^{230} \mathrm{Th}$ source due to self-absorption ${ }^{9 /-11}$. In the dust samples of this study, the efficiency for ${ }^{214} \mathrm{Bi}$ ${ }^{214} \mathrm{Po}$ correlated events $\left[\boldsymbol{\varepsilon}_{\text {corr }}\right]$ is $13.2 \pm 7.1 \%$ under the experimental conditions of $10 \mathrm{~min}$ counting time. The counting efficiency for $\alpha$ ray of ${ }^{214} \mathrm{Po}\left[\varepsilon_{\mathrm{det}}\right]$ is approximately $15 \%$ by the preliminary examination in this sampling point.

\section{$3 \cdot 3$ Measurement of ${ }^{214} \mathrm{Bi}-{ }^{214} \mathrm{Po}$ correlated events}

The time interval spectrum was simulated as several combinations of the ${ }^{214} \mathrm{Bi}-{ }^{214} \mathrm{Po}$ correlated events with the random events. First of all, the spectrum of the electrodeposited ${ }^{230} \mathrm{Th}$ source is obtained as shown in Fig. 5 (a). The measurement data of the ${ }^{214} \mathrm{Bi}-{ }^{214} \mathrm{Po}$ correlated events were subtracted from the measurement data of the electrodeposited ${ }^{230} \mathrm{Th}$ source. The ROIs except for the ${ }^{214} \mathrm{Bi}-{ }^{214} \mathrm{Po}$ correlated events, which are treated as random events,
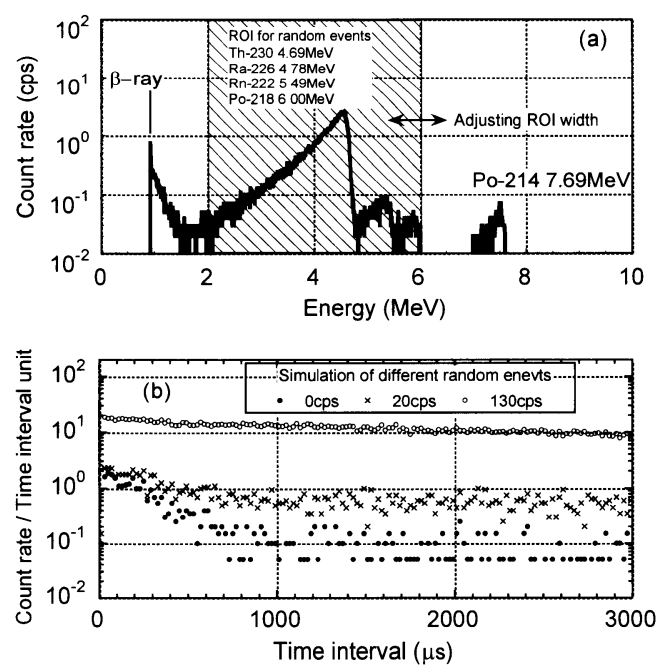

Fig. 5 (a) $\alpha$-ray energy spectrum of the electrodeposited ${ }^{230} \mathrm{Th}$ source. Simulation of the ${ }^{214} \mathrm{Bi}-$ ${ }^{214} \mathrm{Po}$ correlated events including the random events adjusts ROI width from 2 to $6 \mathrm{MeV}$. (b) Changes of time interval spectra of the ${ }^{214} \mathrm{Bi}-{ }^{214} \mathrm{Po}$ correlated events for three different contributions of random events (time interval unit: $10 \mu \mathrm{s})$.

were added to the random events in the measurement data for only the ${ }^{214} \mathrm{Bi}-{ }^{214} \mathrm{Po}$ correlated events by adjusting ROI width. In Fig. 5 (a), the ROI measured from measuring the electrodeposited ${ }^{230} \mathrm{Th}$ source are adjusted in order to simulate effect of the random events for all measurement data.

The time interval spectra, obtained for three combinations between the ${ }^{214} \mathrm{Bi}-{ }^{214} \mathrm{Po}$ correlated events and the random events are shown in Fig. 5(b). Background counts of the random events are increase according to increment of the random events, so that the determination of the ${ }^{214} \mathrm{Bi}-{ }^{214} \mathrm{Po}$ correlated events becomes difficult.

The ${ }^{214} \mathrm{Po}$ radioactivities were analyzed by the procedure of section $2 \cdot 3$. The results were compared with ${ }^{214} \mathrm{Bi}\left({ }^{214} \mathrm{Po}\right)$ radioactivity measured by $\gamma$-ray spectrometry. The determined 


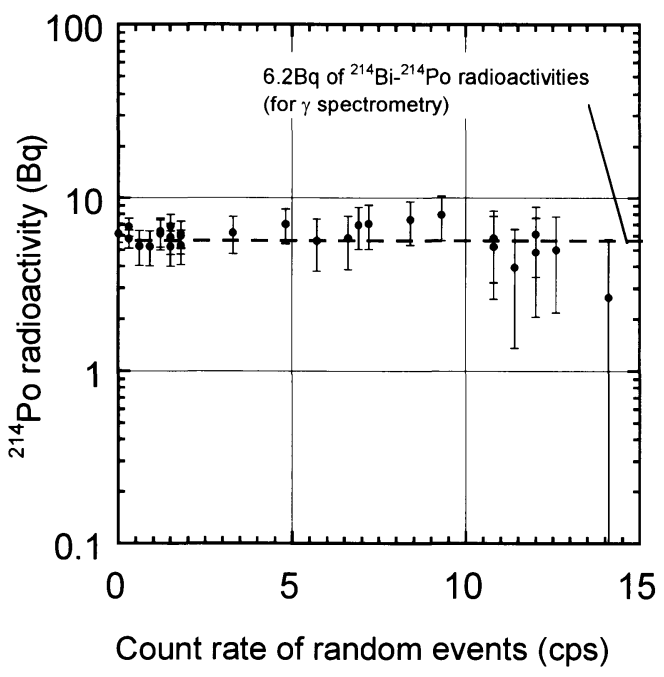

Fig. $6{ }^{214}$ Po radioactivities determined using time interval analysis with various random events.

${ }^{214} \mathrm{Po}$ radioactivities of the electrodeposited ${ }^{230} \mathrm{Th}$ source obtained by the TIA method are shown in Fig. 6. The ${ }^{214} \mathrm{Po}$ radioactivities can be obtained with good reproducibility for counting rate of the random event less than $10 \mathrm{cps}$. However, when the random events are added above $10 \mathrm{cps}$, the ${ }^{214} \mathrm{Po}$ radioactivities include a large uncertainty because of increased background counting rate of the random events.

Detection limit of ${ }^{214} \mathrm{Bi}-{ }^{214} \mathrm{Po}$ correlated events was expressed as a distinguishable criterion between the ${ }^{214} \mathrm{Bi}-{ }^{214} \mathrm{Po}$ correlated events and the random events of the time interval spectrum. Namely, the observed slope is different between the plots in a $0-1 \mathrm{~ms}$ time interval and those after $1 \mathrm{~ms}$ as seen in Fig. 5 (b). The Detection limit of the ${ }^{214} \mathrm{Bi}-{ }^{214} \mathrm{Po}$ correlated events is shown as a function of the random events in Fig. 7. The detection limit of the ${ }^{214} \mathrm{Bi}-$ ${ }^{214} \mathrm{Po}$ correlated events is based on the total $\alpha$ ray counting efficiency (0.15) and the efficiency for ${ }^{214} \mathrm{Bi}-{ }^{214} \mathrm{Po}$ correlated events (0.13) under the experimental conditions of $10 \mathrm{~min}$

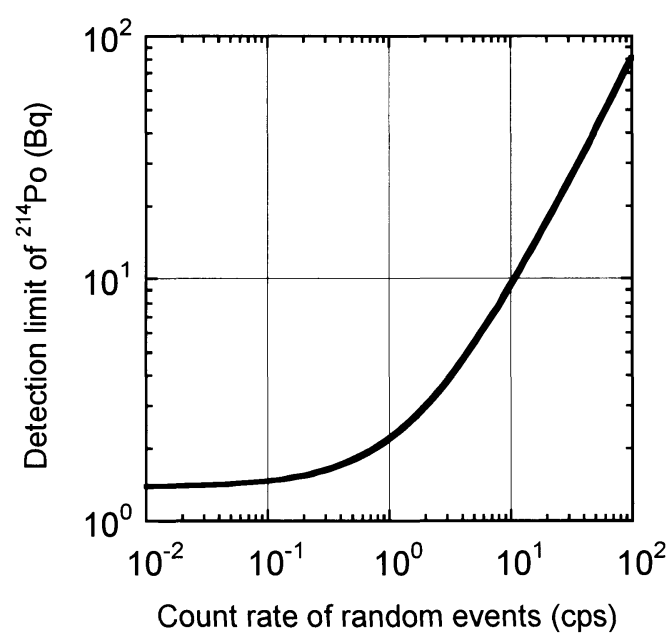

Fig. 7 Detection limits of ${ }^{214} \mathrm{Bi}-{ }^{214} \mathrm{Po}$ correlated events as a function of the random events. The total $\alpha$-ray counting efficiency and the efficiency for the ${ }^{214} \mathrm{Bi}-{ }^{214} \mathrm{Po}$ correlated events were 0.15 and 0.13 , respectively (see section $3 \cdot 2)$.

counting time (see section $3 \cdot 2$ ). The detection limit of ${ }^{214} \mathrm{Bi}-{ }^{214} \mathrm{Po}$ correlated events increases with the random events radioactivity. For example, when the random event radioactivity is from 0.01 to $0.1 \mathrm{cps}$, the detection limit of ${ }^{214} \mathrm{Bi}-$ ${ }^{214} \mathrm{Po}$ correlated events is from 1.0 to $2.1 \mathrm{~Bq}$.

\section{Conclusions}

In this study, radioactivity determination of ${ }^{214} \mathrm{Po}$ using the TIA method with the Si semiconductor detector was carried out due to measuring the electrodeposited ${ }^{230} \mathrm{Th}$ source and the dust samples. This system has the advantage that the ${ }^{214} \mathrm{Po}$ radioactivities could directly measure dust samples including random events on the filter paper. Furthermore, $\alpha$-ray detection of artificial radionuclides could measure reducing the disturbance of $\alpha$-ray due to the Rn-progeny by continuously measurement of the ${ }^{214} \mathrm{Po}$ radioactivities. The measurement system with the TIA methods will be useful 

correlated events in Rn-progeny with a microsecond lifetime

not only for measurement of ${ }^{214} \mathrm{Bi}-{ }^{214} \mathrm{Po}$ correlated event radioactivities on the collected dust, but also for the rapid detection of unexpected release of artificial radionuclides from a nuclear fuel facility.

\section{References}

1) Iimoto, T. and Kurosawa, R., A pulse-coincidence ${ }^{220} \mathrm{Rn}$ monitor with three time-gates, Environ. Int., 22, S1139-S1145(1996)

2) Hayes, R. B., Pena, M. A. and Goff, T. E., Use of alpha spectroscopy for conducting rapid surveys of transuranic activity on air sample filters and smears, Health Phys., 89, 172-180 (2005)

3) Bland, C. J. and Martin Sanchez, A., A direct measurement of ${ }^{228} \mathrm{Th}$ activity by alpha-beta coincidence counting, Nucl. Inst. Meth. Phys. Res. A286, 375-378 (1990)

4) Allen, D. E., Determination of MDA for a two count method for stripping short-lived activity out of an air sample, Health Phys., 73, 512-517 (1997)

5) Misdaq, M. A., Radon, thoron and their progenies measured in different dwelling rooms and reference atmospheres by using CR-39 and LR-115 SSNTD, Appl. Rad. Isot., 59, 273-280 (2003)

6) Hashimoto, T., Yoneyama, Y., Sato, K. and
Komatsu, Y.. Pulse time interval analysis (TIA) combined with liquid scintillation counting for the determination of environmental $\alpha$-nuclides: Preparation and utilization of ${ }^{225} \mathrm{Ra}$ as a yield tracer, J. Radioanal. Nucl. Chem., 239, 619-629 (1999)

7) Hashimoto, T., Sanada, Y. and Uezu, Y., Simultaneous determination of radionuclides separable into natural decay series by use of time-interval analysis, Anal. Bioanal. Chem., 379, 227-233 (2004)

8) Jurado Vargas, M. and Fernandez de Soto, F., A study of ${ }^{222} \mathrm{Rn}$ emanation in electrondeposited sources of ${ }^{226} \mathrm{Ra}$ with barium, Nucl. Inst. Meth. Phys. Res., A368, 488-491 (1996)

9) Iimoto, T., Fujimoto, K., Tokonami, S. and Kurosawa, R., Characteristics of major filters used for ${ }^{222} \mathrm{Rn}$ progeny measurements, Rad. Meas., 29, 161164 (1998)

10) Kinouchi, N., Oishi, T., Noguchi, H., Kato, S. and Ishizuka, M., Selection of filter media used for monitoring airborne alpha-emitting particles in a radiological emergency, RADIOISOTOPES, 50, 403-407 (2001)

11) Luetzelschwab, J. W., Storey, C., Zraly, K. and Dussinger, D., Self absorption of alpha and beta particles in a fiberglass filter, Health Phys., 79, $425-430(2000)$ 


\section{パルス時間間隔解析法を用いたマイクロ秒半隇期のラドン子孫核種の選択的な測定}

眞田幸尚, 小林博英, 古田定昭, 根本和彦*, 川井啓一*, 橋本哲夫**

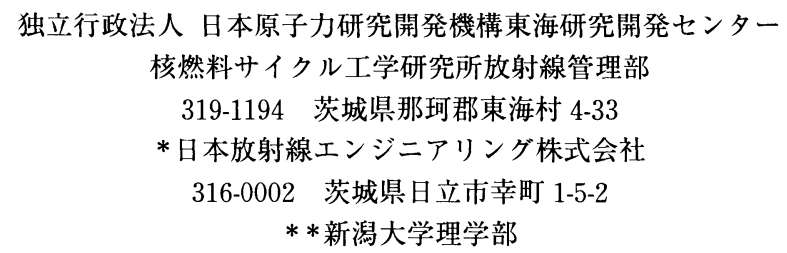

950-2181 新潟県新潟市五十嵐 8050-2

同時計数法の一種であるパルス時間間隔解析法を用いて， $\beta-\alpha$ 相関事象を選択的に測定した。 測定システムは, $\mathrm{Si}$ 半導体検出器で測定した放射線パルス間の時間間隔を測定できる構成とし, ${ }^{214} \mathrm{Po}$ の半隇期 $(164 \mu \mathrm{s})$ を考慮して不感時間の短い設計とした。本研究では, ${ }^{230} \mathrm{Th}$ の電着線源を使用 してシステムの基本的な性能を調べた。隣接した時間間隔のデータをパルス時間間隔解析法の一つ である隣接時間間隔解析法（STA）により解析した。

結論は，次のようにまとめられる。

（1） Rn 子孫核種に属するマイクロ秒単位の半減期の相関事象を測定した。（2）パルス時間間隔 解析法を利用した ${ }^{214} \mathrm{Po}$ 測定の理論を確立した。（3） ${ }^{214} \mathrm{Po}$ の測定システムを開発した。（4） ${ }^{230} \mathrm{Th}$ 電 着線源を用いてシステムの有効性及び検出限界について示した。

本研究は, ラドン子孫核種のバックグラウンドの変化を補償することによって, 人工放射性核種 の混入を検出するための $\alpha$ 線モニタリング手法として応用が期待できる。 